\title{
Oral administration of protease inhibits enterotoxigenic Escherichia coli receptor activity in piglet small intestine
}

\author{
T L Mynott, R K J Luke, D S Chandler
}

\begin{abstract}
The virulence of enterotoxigenic Escherichia coli (ETEC) is attributed to their ability to adhere via fimbrial adhesins to specific receptors located on the intestinal mucosa. A novel approach to preventing ETEC induced diarrhoea would be to prevent attachment of ETEC to intestine by proteolytically modifying the receptor attachment sites. This study aimed to examine the effect of bromelain, a proteolytic extract obtained from pineapple stems, on ETEC receptor activity in porcine small intestine. Bromelain was administered orally to piglets and $\mathrm{K88}^{+}$ ETEC attachment to small intestine was measured at $50 \mathrm{~cm}$ intervals using an enzyme immunoassay. $\mathrm{K88}^{+}$ETEC attachment to intestinal sections that were not treated with bromelain varied appreciably between sampling sites. Variability in receptor activity along the intestinal surface is thought to be caused by the localised effects of endogenous proteases. Oral administration of exogenous protease inhibited $\mathrm{K88}^{+}$ETEC attachment to pig small intestine in a dose dependent manner $(p<0.05)$. Attachment of $\mathrm{K88}^{+}$ ETEC was negligible after treatment, resembling the levels of attachment of $\mathrm{K88}$ to piglets of the genetically determined non-adhesive phenotype, which are resistant to $\mathrm{K88}^{+}$ETEC infection. Serum biochemical analysis and histopathological examination of treated piglets showed no adverse effects of the bromelain treatment. It is concluded that administration of bromelain can inhibit ETEC receptor activity in vivo and may therefore be useful for prevention of $\mathrm{K88}^{+}$ETEC induced diarrhoea.
\end{abstract}

(Gut 1996; 38: 28-32)

Keywords: enterotoxigenic Escherichia coli, diarrhoea, K88 ETEC, pig intestine, protease.

Victorian Institute of Animal Science, Department of Agriculture, Attwood, Victoria 3049, Australia

T L Mynott

D S Chandler

Correspondence to: Dr T L Mynott, Digestive Diseases Research Centre, The Medical College of Sain Bartholomew's Hospital, 4th Floor Science Block, Charter House Square, London EC1M 6BQ. United Kingdom.

Accepted for publication 31 May 1995

Enterotoxigenic Escherichia coli (ETEC) are an important cause of disease in young children ${ }^{1}$ and young animals. ${ }^{2}$ The virulence of ETEC strains is attributed to their ability to adhere, via fimbrial adhesins, to highly specific receptors located on the intestinal mucosa. ${ }^{3}$ These strains also liberate heat labile (LT) and/or heat stable (ST) enterotoxins which cause fluid secretion and diarrhoea. $E$ coli strains which carry the $\mathrm{K} 88$ adhesin on their surface are a significant cause of diarrhoea in young piglets. ${ }^{4} \mathrm{~K} 88$ occurs in several antigenic types or variants, all of which adhere to piglet enterocytes. ${ }^{5} \mathrm{~K} 88 \mathrm{ab}$, K88ac, K88ad, and K88ad(e) variants have been characterised. ${ }^{67}$

In 1975 , Rutter et al ${ }^{8}$ showed that some pigs are resistant to colonisation and disease caused

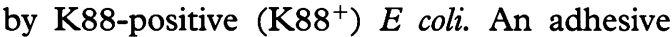
phenotype (one susceptible to infection) is related directly to the ability of $\mathrm{K} 88^{+}$bacteria to recognise intestinal receptors and attach to piglet intestinal brush border membranes. Intestine obtained from the non-adhesive phenotype (disease resistant pigs) do not bind $\mathrm{K}^{+} 8^{+} E$ coli and as a result such animals are resistant to $\mathrm{K}^{\circ} 8^{+} E$ coli infection. ${ }^{9}$ The receptors on non-adhesive intestinal brush border cells may be absent or non-functional. A genetic basis for expression of the adhesive or non-adhesive phenotype exists. ${ }^{810}$ Different phenotypes may also be distinguished, depending on the serological variant of the K88 antigen. ${ }^{11}$ Also, in addition to genotype, physiological factors, particularly the level of intestinal proteolysis within the small intestine, may influence the ability of ETEC to attach to intestine. ${ }^{12} 13$

The ability of protease to prevent attachment of ETEC to small intestinal samples in vitro is well documented. ${ }^{13-18}$ Presumably attachment ability is prevented because of proteolytic cleavage of ETEC receptor sites. This study aimed to investigate whether exogenous protease, administered orally, could inhibit porcine $\mathrm{K}^{+} 8^{+}$ETEC receptor activity in vivo and therefore inhibit $\mathrm{K}^{\circ} 8^{+}$ETEC attachment to small intestine. The use of protease, through its ability to modify intestinal receptor sites and reduce the binding properties of the intestinal mucosa, may be an important way of protecting the small intestine from microbial colonisation and disease. ${ }^{12} 13$

\section{Methods}

ANIMALS

Approval for animal experiments was granted by the Victorian Institute for Animal Science Animal Experimentation Ethics Committee. Five pregnant sows (Large White X Landrace $X$ Duroc) were purchased from a commercial farm where the incidence of pigs with the nonadhesive phenotype is low (1 in 10). ${ }^{19}$ Piglets were born within three days of each other in the animal housing facility at the Victorian Institute of Animal Science (VIAS-Attwood, Victoria, Australia). Piglets were weaned at approximately 3 weeks of age (weight not less 
$\mathrm{K}^{8} 8^{+}$enterotoxigenic Escherichia coli (ETEC) attachment to piglet small intestine

\begin{tabular}{|c|c|c|c|c|c|}
\hline \multirow[b]{2}{*}{ Group* } & \multirow{2}{*}{$\begin{array}{l}\text { Protease } \\
(m g) t\end{array}$} & \multicolumn{3}{|c|}{ K88 receptor activity (mean $(S D)) \neq$} & \multirow{2}{*}{$\begin{array}{l}\text { Non-adhesive } \\
(\%) \pi\end{array}$} \\
\hline & & Strongf & Moderate & Non-adhesive & \\
\hline A & 0 & $\begin{array}{l}0.409(0.244) \\
0.709(0.090)\end{array}$ & $\begin{array}{l}0.211(0.178) \\
0.311(0.108) \\
0.230(0.095)\end{array}$ & $\begin{array}{l}0.078(0.029) \\
0.069(0.045)\end{array}$ & 29 \\
\hline B & 125 & $0.660(0.096)$ & $\begin{array}{l}0.295(0.139) \\
0.312(0.187)\end{array}$ & $\begin{array}{l}0.080(0.099)_{(2)} \\
0.119(0.071)_{(2)} \\
0.034(0.014)_{(2)} \\
0.055(0.026)\end{array}$ & 57 \\
\hline C & 250 & nil & $0.359(0.225)_{(2)}$ & $\begin{array}{l}0.061(0.027)_{(2)} \\
0.079(0.057)_{(2)} \\
0.039(0.013)_{(2)} \\
0.191(0.117) \\
0.045(0.017) \\
0.044(0.021)\end{array}$ & 86 \\
\hline $\mathrm{D}$ & 625 & nil & $0.224(0.195)_{(2)}$ & $\begin{array}{l}0.096(0.036)_{(2)} \\
0.176(0.118) \\
0.033(0.015)_{(2)} \\
0.099(0.115)_{(2)} \\
0.034(0.015) \\
0.064(0.022)\end{array}$ & 86 \\
\hline E & 1250 & nil & $0 \cdot 238(0 \cdot 183)$ & $\begin{array}{l}0.036(0.015)_{(2)} \\
0.059(0.015)_{(2)} \\
0.032(0.009)_{(2)} \\
0.050(0.040)_{(2)} \\
0.033(0.015) \\
0.182(0.135)\end{array}$ & 86 \\
\hline
\end{tabular}

«Number of pigs per group is 7. †Amount of bromelain administered per dose, three times a day for either two (2) days $(n=4)$ or five days $(n=3)$. There was no significant difference between duration of treatment and reduction in EIA activity $(p=0 \cdot 82)$. Ability of protease to reduce K88 duration of treatment and reduction in EIA activity $(p=0 \cdot 82)$. Ability of protease to redu absorbance of the $A_{540} \mathrm{~nm}$ value of 19 sampling sites per pig. The large SD observed in some pigs reflect the variability of receptor activity along the length of the small intestine. $\$ \mathrm{~K} 88^{+}$ ETEC attachment expressed as strongly adhesive (EIA activities $>0 \cdot 4$ ); moderately adhesive (EIA activities $0 \cdot 20$ to $0 \cdot 40$ ); and non-adhesive (EIA activity $<0 \cdot 2$ ). $\pi$ Number of K88 ${ }^{+}$ETEC non-adhesive versus number tested expressed as a percentage. Of the total number of pigs treated with protease, $79 \%$ (22 of 28 ) were non-adhesive compared with $29 \%$ (2 of 7$)$ pigs not treated with protease $(p<0.02$, Fisher's exact test).

than $6 \mathrm{~kg}$ ), and housed in stables with straw bedding. Piglets were fed ad libitum a commercial starter diet (Gropower, Barastoc, Australia) for two weeks after weaning, followed by Grower 8 (Barastoc, Australia) in three divided meals $(160 \mathrm{~g} / 6 \mathrm{~kg}$ of body weight daily) until experimentation. Thirty five piglets of weight 20 to $25 \mathrm{~kg}$ (aged 10 to 16 weeks) were used for the study and randomly allocated between five treatment groups (Table).

\section{PIGLET TREATMENT}

Bromelain (E.C. 3.4.22.4) is a cysteine protease obtained from pineapple stems. Bromelain is a glycoprotein and active across a wide $\mathrm{pH}$ range, therefore it is ideally suited for the gastrointestinal environment. Different amounts of enteric protected bromelain (Detach, Cortecs Ltd, Middlesex UK; 1 g of Detach contains $125 \mathrm{mg}$ of bromelain) was administered to pigs for two or five days to investigate the effect of duration of treatment on $\mathrm{K}^{8} 8^{+}$ETEC receptor activity and to investigate the safety of treatment. The bromelain preparation was suspended in water (1g per 5 $\mathrm{ml}$ ) and administered by mouth using a plastic syringe, three times a day $15 \mathrm{~min}$ before feeding (Table). Control piglets were untreated and administered $25 \mathrm{ml}$ of water. All animals were monitored daily to observe any adverse clinical effects attributable to treatment. At the completion of the experiment animals were killed by barbiturate overdose, and autopsied.

ASSESSMENT OF K88 PHENOTYPE BY ENZYME IMMUNOASSAY (EIA)

The small intestine (length from pyloris to the terminal ileum was 8 to $10 \mathrm{~m}$ ) of all pigs was removed immediately at death. Brush border material was obtained at $50 \mathrm{~cm}$ intervals ( $n=19$ samples per pig) by gently scraping 1 $\mathrm{cm}$ sections of the villous surface with a sterile cotton-tipped swab. The swabs were then immersed in $3 \mathrm{ml}$ of a working dilution buffer (WDB) consisting of phosphate buffered saline (PBS; $0 \cdot 1 \mathrm{M}, \mathrm{pH} \mathrm{7.4)}$ to which bovine serum albumin (BSA; 0.25\% w/v), EDTA (di-sodium salt; $1 \mathrm{mM})$, Tween $20(0.05 \% \mathrm{v} / \mathrm{v})$ and sodium azide $(0.02 \% \mathrm{w} / \mathrm{v})$ had been added. The swabs were vortexed to recover the epithelial cells. Brush border samples were assessed for their ability to attach to ${\mathrm{K} 88^{+}}^{+}$ETEC (strain WG (0149:K91(B):K88ac:H10) ${ }^{20}$ by enzyme immunoassay (EIA) as previously described. ${ }^{1321}$ The EIA gives $95 \%$ correlation with results obtained by traditional microscopic adhesion tests for assessing K88 phenotype $^{21}$ (piglets genetic propensity to produce K88 receptor on its intestinal surface). Briefly, $\mathrm{K88}^{+}$ETEC are immobilised to wells of a microtitre plate and incubated with mucosal samples. Mucosal material, bound to the bacteria is detected with antibody (rabbit IgG) raised against porcine intestine followed by urease-conjugated goat anti-rabbit IgG (Sigma) and urea substrate.

Disposable polystyrene microtitre plates (Nunc, Denmark) were used for all assays. $\mathrm{K}^{2} 8^{+}$ETEC diluted to approximately $2 \times 10^{9}$ bacteria $/ \mathrm{ml}$ in sodium bicarbonate buffer $\left(\mathrm{NaHCO}_{3} \mathrm{Na}_{2} \mathrm{CO}_{3} ; 0.1 \mathrm{M}, \mathrm{pH} 9 \cdot 6\right)$, were adsorbed to wells $(100 \mu 1 /$ well $)$ by incubation overnight at $4^{\circ} \mathrm{C}$. Active binding sites remaining on wells following coating procedures were routinely blocked by incubation $(30 \mathrm{~min}$ at $\left.37^{\circ} \mathrm{C}\right)$ with BSA $(1 \% \mathrm{w} / \mathrm{v})$ dissolved in PBS (200 $\mu \mathrm{l} /$ well). Mucosal material bound to $\mathrm{K}^{\circ} 8^{+}$ETEC was detected using rabbit IgG raised against a Triton X-100 extract of K88adhesive phenotype brush border vesicles, diluted in WDB. ${ }^{21}$ Anti-rabbit urease-conjugated IgG (Sigma) was diluted in WDB containing ovalbumin (from hen egg, grade II, Sigma $1 \% \mathrm{w} / \mathrm{v}$ ). All incubation steps, excluding the coating procedures, were performed at $37^{\circ} \mathrm{C}$ for 30 minutes. Between each of the incubation steps, supernatant liquid was removed from the wells which were then washed three times with washing buffer $(0 \cdot 1 \mathrm{M}$ PBS; $0.05 \%$ v/v Tween 20 ). Before the incubation with substrate, wells were washed with distilled water to remove any effect of residual buffer on substrate solutions. Urea substrate [bromocresol purple $(0 \cdot 15 \mathrm{mM})$ urea $(16 \mathrm{mM})$, EDTA (disodium salt, $1 \mathrm{mM}$ ); $\mathrm{pH} 4 \cdot 8,100$ $\mu \mathrm{l} /$ well] was used to detect the presence of bound, conjugated enzyme. A positive reaction was indicated by a colour change from yellow to purple which was measured spectrophotometrically at $A_{540 \mathrm{~nm}}$. All assays were standardised by developing the reaction until a positive control attained an EIA value of $0 \cdot 6$.

The K88 phenotype of the intestine scrapings was assessed and an adhesion pattern for the small intestine of each pig was established. To obtain an overall indication of the 
K88-adhesiveness of a pig, the mean EIA value of all sampling sites ( $n=19$ per pig) was determined. The adhesiveness of a particular pig could be designated as strongly adhesive (S; mean EIA $>0.4$ ); moderately adhesive (M; mean EIA 0.2 to 0.4 ) or non-adhesive $(\mathrm{N} ;$ mean EIA $<0 \cdot 2)$. (See Table.)

\section{SERUM BIOCHEMISTRY}

Blood samples $(10 \mathrm{ml})$ were collected from piglets via the jugular vein one day before experimentation and again immediately before death. Serum samples were stored at $-20^{\circ} \mathrm{C}$ until completion of the experiment, at which time they were submitted for biochemical analysis. Tests performed include a full biochemical profile, liver function tests, creatinine kinase, lipase, and amylase. As normal values for biochemical parameters cited in the literature vary because of factors such as differences in sample handling, assay technique, dietary influences or genetic differences between animals, pre-treatment values were taken as an indication of baseline normal values. These values were within the normal ranges cited in the literature. ${ }^{22} 23$ Differences between serum samples before and after treatment were compared for each pig. In addition, the mean serum value for each parameter for the treated groups was compared with that for the nontreatment group.

\section{HISTOPATHOLOGY}

All animals were sacrificed by barbiturate overdose two or five days after beginning treatment. At autopsy, specimens were immediately processed for histological examination after fixation with neutral buffered formalin $(0.65 \%$ (w/v) $\mathrm{Na}_{2} \mathrm{HPO}_{4}, 0.45$ (w/v) $\mathrm{NaH}_{2} \mathrm{PO}_{4}, 10 \%$ (v/v) formalin). Sections of duodenum, midjejunum, and ileum, were stained with haematoxylin and eosin and examined by light microscopy for morphological changes. Sections of heart, kidney, liver, and mesenteric lymph nodes were also investigated.

\section{STATISTICAL ANALYSIS}

Differences in biochemical parameters, between serum samples, before and after treatment, and differences between treatment groups were assessed for clinical relevance by veterinary pathologists at VIAS-Attwood. Differences among mean serum biochemical values between treatment groups were subjected to one-way analysis of variance (ANOVA) using Microstat. Difference among mean EIA values for all treatment groups ( 0 $\mathrm{mg}$ to $1250 \mathrm{mg}$ ) representing mean ${\mathrm{K} 88^{+}}^{+}$ ETEC receptor activity was analysed by Genestat V for analysis of variance.

\section{Results}

$\mathrm{K}^{8} 8^{+}$ETEC ATTACHMENT TO SMALL INTESTINE OF UNTREATED (CONTROL PIGS) We first examined the ability of $\mathrm{K}^{+} 8^{+}$ETEC to attach to the small intestine of pigs that were not treated with bromelain (group A). The Table summarises the results obtained from all untreated pigs. Two pigs were of the strongly adhesive phenotype, three pigs were moderately adhesive and two pigs were of nonadhesive phenotype. Figure 1 shows EIA values obtained from intestine of three pigs to show the three phenotypes obtained.

We next compared the binding of $\mathrm{K} 88^{+}$ ETEC to different sections of intestine in individual pigs. $\mathrm{K}^{+} 8^{+}$ETEC attachment to intestine varied markedly between samples taken at $50 \mathrm{~cm}$ intervals (Fig 1). Multiple scrapings taken at the same site revealed similar results indicating that the variability between sites was a function of that section of intestine, not the assay. Earlier, Chandler et al ${ }^{13}$ observed a similar variation in binding between sampling sites and related this variation to the state of distention or constriction of the small intestine at the sampling site. Despite the variation seen between individual scrapings, a consistent pattern was observed

d
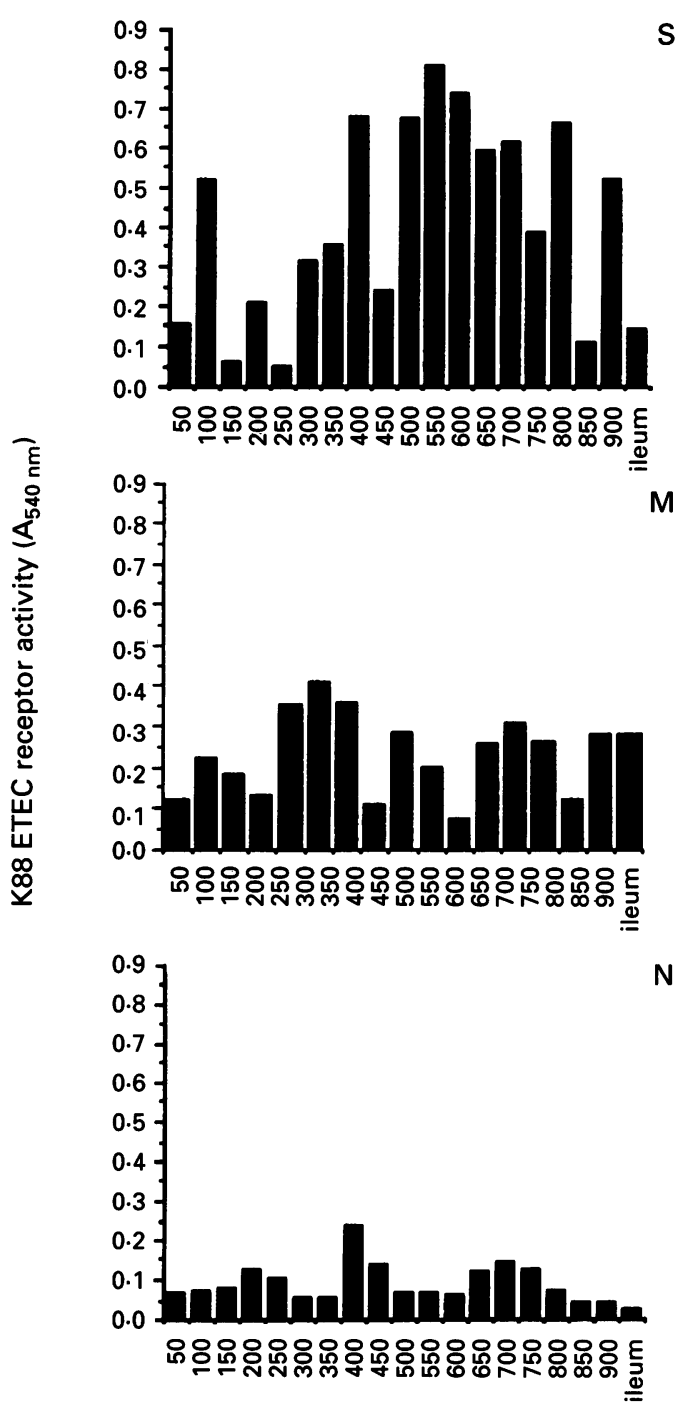

Distance along small intestine $(\mathrm{cm})$

Figure 1: Use of enzyme immunoassay to demonstrate variability in $\mathrm{K}^{88^{+}}$enterotoxigenic Escherichia coli (ETEC) receptor activity and attachment of ETEC to three untreated pigs. Columns represent the mean absorbance of the $A_{540 \mathrm{~nm}}$ values of duplicate wells. $S$, strongly adhesive; $M$, moderately adhesive; $N$, nonadhesive. 


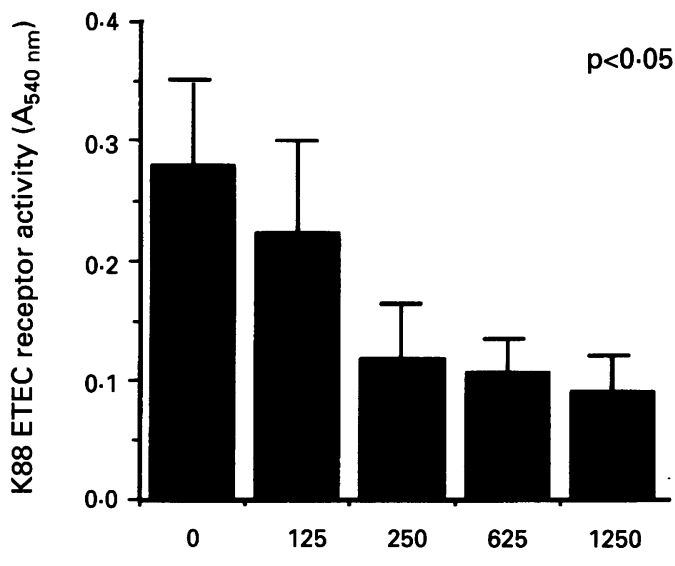

Bromelain dose (mg, 3 times/d)

Figure 2: $\mathrm{K}^{8+} 8^{+}$enterotoxigenic Escherichia coli ETEC receptor activity of small intestine samples of pigs treated with bromelain or untreated. Columns with bars represent the mean (SEM) $A_{540 \mathrm{~nm}}$ values of 19 samples taken from each pig ( $n=7$ pigs per group). The reduction in enzyme immunoassay activity was significant $(p<0.05)$.

between segments. The mid-small intestine typically had high EIA values, indicative of high levels of $\mathrm{K} 88$ receptor activity and therefore $\mathrm{K}^{8} 8^{+}$ETEC attachment. In comparison, the duodenum and the ileum had lower attachment activity, as observed previously. ${ }^{13}$

\section{$\mathrm{K}^{\circ} 8^{+}$ETEC ATTACHMENT ACTIVITY IN PROTEASE TREATED PIGS}

To investigate whether exogenous bromelain could inhibit K88-attachment to piglet intestine, we orally administered different amounts of the protease and measured the ability of K88 to attach to intestine after treatment. Figure 2 shows mean EIA values for each treatment group. A dose-dependent inhibition of $\mathrm{K} 88$ attachment to pig intestine is observed. An analysis of variance revealed a significant treatment effect $(p<0.05)$, confirming that the reduction in $\mathrm{K}^{+} 8^{+}$ETEC receptor binding activity was dependent on the protease and not a result of inherent variation. Bromelain administered in amounts of $250 \mathrm{mg}$ or more were most effective in reducing $\mathrm{K}^{8} 8^{+}$ETEC attachment. In groups $\mathrm{C}, \mathrm{D}$ and $\mathrm{E}$, which received $250 \mathrm{mg}, 625 \mathrm{mg}$ or $1250 \mathrm{mg}$ of protease per dose, six of seven $(87 \%)$ pigs in each group were non-adhesive after treatment $(p<0.05)$ in comparison with only two of seven $(29 \%)$ in untreated pigs (Table). Of the 28 pigs receiving protease, 22 were non-adhesive $(79 \%)$ in comparison with $29 \%$ in non-protease treated pigs $(p<0.02$, Fischer's exact test).

\section{CLINICAL OBSERVATIONS}

Because of the direct effect of an exogenous protease on the intestine, we conducted some preliminary serological and histopathological examination of samples obtained from pigs to investigate any adverse effects of treatment. We observed no abnormal morphological changes in tissue specimens, even at the highest protease treatment level. There was no clinical or statistical difference $(p>0 \cdot 2)$ in any of the parameters measured in samples before and after treatment (data not shown). Pre- and post treatment parameters measured remained within the normal range. ${ }^{22} 23$

\section{Discussion}

Attachment of $\mathrm{K} 88^{+}$enterotoxigenic $E$ coli to specific receptors located on the intestinal brush border is an important initial factor in the establishment of diarrhoeal disease. The receptors for K88ac ETEC have been described as mucin-type sialoglycoproteins. ${ }^{24}$ In vitro, protease treatment of intestinal brush border cells containing these receptors inhibits receptor activity and therefore prevents attachment of ${\mathrm{K} 88^{+}}^{+}$ETEC. Similarly, protease treatment of human and calf small intestine inhibits receptor activity and attachment of ETEC strains which carry the CFA/I and CFA/II, and K99 adhesins, isolated from human and calf diarrhoea, respectively. ${ }^{1625}$ Because of ETEC receptor sensitivity to protease, one possible way of preventing ETEC diarrhoea would be to prevent attachment of bacteria to intestine by proteolytically modifying receptor attachment sites. ${ }^{12} 13$ In the present study, we investigated whether oral administration of bromelain, a cysteine protease, could inhibit $\mathrm{K} 88^{+}$ETEC receptor activity in vivo and therefore inhibit K88 attachment to porcine small intestine.

In pigs that were not treated with bromelain, K88 receptor activity varied appreciably along the length of the small intestine. This variability supports our earlier observations ${ }^{13}$ and those of others investigating ETEC receptor activity in small intestine obtained from calves and lambs. ${ }^{26}$ Variable patterns in receptor activity may reflect masking of receptor sites or release of receptors from the intestinal epithelium in vivo. ${ }^{27}$ Alternatively, the fluctuating levels of receptor activity may reflect the action of endogenous enzymes in that part of the intestine. Several observations support a role for protease modification of intestinal receptors in vivo. ETEC receptor sites have been shown to be readily inactivated by trypsin ${ }^{14}$ and by intestinal contents with high proteolytic activity. ${ }^{13}$ Also, stabilisation of K88 receptor can be achieved by the addition of trypsin inhibitor to sample collection buffers. ${ }^{13}$ Furthermore, pancreatic proteases are known to play a role in the final processing of microvillus proteins, and affect the release of some membrane-bound proteins into the lumen of the small intestine. ${ }^{2829}$ Some of the proteins that are released may be receptors for bacteria.

To confirm an effect of protease on ETEC receptor sites in vivo, we administered various amounts of protease orally to piglets. Exogenous protease, administered orally inhibited $\mathrm{K}^{2} 8^{+}$ETEC receptor activity and therefore ETEC attachment to small intestine. The effect of bromelain on K88 receptor activity was dose dependent, in that binding activity decreased with increased protease dose rate $(p<0.05)$. Presumably, the protease modified ${\mathrm{K} 88^{+}}^{+}$ETEC enterocyte receptor sites, such that $\mathrm{K}^{8} 8^{+}$bacteria could no longer 
recognise and attach to the small intestinal brush border.

The pattern of non-adhesiveness observed in protease treated pigs resembled that observed in pigs of the genetically determined, non-adhesive phenotype. Piglets of the nonadhesive phenotype are resistant to $\mathrm{K} 88^{+}$ ETEC infection because they lack functional receptors for ETEC. ${ }^{89}$ Therefore, the inability

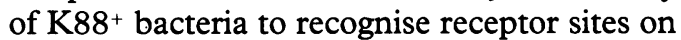
the small intestine of bromelain treated piglets should render the animals resistant to colonisation by these bacteria and prevent diarrhoeal disease. We have previously shown that the oral administration of enteric-coated bromelain to rabbits inhibits colonisation of $\mathrm{CFA} / \mathrm{I}^{+}$ $\mathrm{ST}^{+} \mathrm{LT}^{+} E$ coli $(\mathrm{H} 10407)$ and protects against diarrhoea and diarrhoea induced death. ${ }^{12}$ Further studies have demonstrated that bromelain significantly reduces diarrhoea in piglets challenged with $\mathrm{K} 88^{+}$ETEC (Chandler and Mynott, manuscript in preparation).

The data in this study support the view that increased proteolytic activity in the intestine favours low receptor activity, and hence resistance to ETEC colonisation. In addition to acidity in the stomach, local intestinal immunity, the flushing action of intestinal peristalsis, and competition with commensal organisms, intestinal proteolysis may be a previously undescribed host-defense mechanism. The novel concept of host receptor modification by oral administration of protease is a new approach to disease control that could provide broad spectrum protection and obviate the potential difficulty of antigenic variability of microbial virulence determinants.

The authors thank Leigh Callinan, Biometric Services, Victorian Department of Agriculture, (Bendigo, Victoria, Australia) for conducting the Genestat analysis. We would also like to thank Jim Parsons and Mike Forsyth, VIAS-Attwood (Victoria, Australia) for histopathological assessment of tissues and evaluation of serological parameters, respectively. We also acknowledge discussions with Ray King, VIAS-Werribee (Victoria Australia) on the estimated daily feed intake of pigs. Serum biochemistry analysis were conducted by the Biochemistry Department at VIAS-Attwood. T $M$ thanks Jim Nataro, Christian Engwerda, and Mike Field for comments on the manuscript and acknowledges the support of Cortecs Ltd.

1 Cravioto A, Reyes RE, Ortega R, Fernandez G, Hernandez $\mathrm{R}$, Lopez D. Prospective study of diarrhoeal disease in a cohort of rural Mexican children: incidence and isolated pathogens during the first two years of life. Epidem Inf pathogens during the

2 Smith HW, Lingood MA. Further observations on Escherichia coli enterotoxins with particular regard to those produced by atypical piglet strains and by calf and lamb strains: the transmissible nature of these enterotoxins and of a $\mathrm{K}$ antigen possessed by calf and lamb strains. $\mathcal{f} \mathrm{Med}$ Microbiol 1982; 5: 243-50.

3 Gaastra W, de Graaf FK. Host specific fimbrial adhesins of non-invasive enterotoxigenic Escherichia coli strains. Microbiol Rev 1982: 46: 129-61.

4 Jones GW, Rutter JM. Role of the K88 antigen in the pathogenesis of neonatal diarrhoea caused by Escherichia coli in penesis of neonatal diarrhoea caused by

5 Cox E. Houvenaghel A. In vitro adhesion of K88ab-, K88ac- and K88ad-positive Escherichia coli to intestinal villi, to buccal cells and to erythrocytes of weaned piglets. Vet Microbiol 1987; 15: 201-7.

6 Mooi FR, de Graaf FK. Isolation and characterisation of K88 antigens. FEMS Microbiol Lett 1979; 5: 17-20.

7 Klemm P. Fimbrial adhesins of Escherichia coli. Rev Infect Dis 1985; 7: 321-40.

8 Rutter JM, Burrows MR, Sellwood R, Gibbons RA. A genetic basis for resistance to enteric disease caused by Escherichia coli. Nature 1975; 257: 135-6.

9 Sellwood R, Gibbons RA, Jones GW, Rutter JW. Adhesion of enteropathogenic Escherichia coli to pig intestinal brush borders: the existence of two pig phenotypes. $\mathcal{F}$ Med Microbiol 1975; 8: 405-10.

10 Gibbons RA, Sellwood R, Burrows M, Hunter PA. Inheritance of resistance to neonatal Escherichia coli diarrhoea in the pig. Examination of the genetic system. Theor Appl Genet 1977; 51: 65-70.

11 Bijlsma IGW, de Nijs A, Van der Meer C, Frik JF. Different pig phenotypes affect adherence of Escherichia coli to jejupig phenotypes affect adherence of Escherichia coli to jejuInfect Immun 1982; 3: 891-94.

12 Mynott TL, Chandler DS, Luke RKJ. Efficacy of entericcoated protease in preventing attachment of enterotoxigenic Escherichia coli (ETEC) and diarrhoeal disease in the RITARD model. Infect Immun 1991; 59: 3708-14.

13 Chandler DS, Mynott TL, Luke RKJ, Craven JA. The distribution and stability of the Escherichia coli K88 receptor in the gastrointestinal tract of the pig. Vet Microbiol 1994; 38: 203-15.

14 Staley TE, Wilson JB. Soluble pig intestinal cell membrane components with affinities for Escherichia coli $\mathrm{K}^{8} 8^{+}$antigen. Mol Cell Biochem 1983; 52: 177-89.

15 Laux DC, McSweegan EF, Williams TJ, Wadolkowski EA, Cohen PS. Identification and characterisation of mouse small intestine mucosal receptors for Escherichia coli K-12 (K88ab). Infect Immun 1986; 52: 18-25.

6 Mouricout MA, Julien RA. Pilus mediated binding of bovine enterotoxigenic Escherichia coli to calf small intestinal mucins. Infect Immun 1987; 55: 1216-23.

17 Metcalfe JW, Krogfelt KA, Krivan HC, Cohen SC, Laux DC. Characterisation and identification of a small intestine mucus receptor for the K88ab fimbrial adhesin. Infect Immun 1991; 59: 91-96.

18 Mynott TL, Chandler DS. Receptor modification: a novel approach to prevent disease caused by enterotoxigenic approach to prevent disease caused by enterotoxigenic Meeting of the American Society for Microbiology 1993. Meeting of the Ame

19 Chandler DS. Inherited resistance of $\mathrm{K}^{8} 8^{+}$Escherichia coli in pigs. 1986. Ph.D Thesis. School of Agriculture, La Trobe University, Bundoora, Victoria, Australia.

20 Tzipori S, Chandler DS, Smith M, Makin TJ, Hennessy D. Factors contributing to postweaning diarrhoea in a large intensive piggery. Aust Vet $\mathcal{F} 1980 ; 56: 274-8$.

21 Chandler DS, Chandler HM, Luke RKJ, Tzipori SR, Craven JA. Screening of pig intestine for K88 non-adhesive phenotype by enzyme immunoassay. Vet Microbiol 1986; 11: 153-61.

22 Kaneko JJ (ed.). In: Clinical biochemistry of domestic animals. 3rd ed. New York: Academic Press, 1980; 790-6.

23 Mitruka BM, Rawnsley HM (eds.). In: Clinical biochemical and haematological reference values in normal experimental animals and normal humans. New York: Masson Publishing, 1982; 216-54

24 Erickson AK, Baker DR, Bosworth, BT, Casey TA, Benfield DA, Francis DH. Characterisation of porcine intestinal receptors for the K88ac fimbrial adhesin of Escherichia coli as mucin-type sialoglycoproteins. Infect Immun 1994; 62: 5404-10.

25 Mynott TL, Luke RKJ, Chandler DS. Detection of attachment of enterotoxigenic Escherichia coli (ETEC) to human small intestinal cells by enzyme immunoassay. FEMS small intestinal cells by enzyme immun

26 Sellwood R, Lees D. Adhesion of Escherichia coli pathogenic in pigs, calves and lambs to intestinal epithelial cell brush borders. In: de Leeuw PW, Guinee PAM eds, Laboratory diagnosis in neonatal calf and pig diarrhoea. Current topics in veterinary medicine and animal science. 1980; 13: 163-70.

27 Dean EA, Whipp S, Moon H. Age-specific colonisation of porcine intestinal epithelium by $987 \mathrm{P}$-piliated enterotoxigenic Escherichia coli. Infect Immun 1989; 57: 82-7.

28 Hauri HP, Quaroni A, Isselbacher KJ. Biogenesis of intestinal plasma membrane: post-translational route and cleavage of sucrase-isomaltase. Proc Natl Acad Sci USA 1979; 76: 5183-6.

29 Kidder DE, Manners MJ. In: Digestion in the pig. Bristol: Wright-Scientechnica, 1978 